\title{
ANALISIS PENGARUH INFRASTRUKTUR EKONOMI TERHADAP PRODUK DOMESTIK BRUTO DI INDONESIA
}

\author{
Oleh: \\ Eko Fajar Cahyono \\ Fakultas Ekonomi Universitas Islam Negeri Malang \\ E-mail/No.Hp: eko_cah@gmail.com
}

\begin{abstract}
This research intent to measure one how far public infrastructure influence as highway, electricity,fresh water and telephone and seluler to Gross Domestic Product at Indonesia. This research goes upon on classic economic growth theory and neoklasik what does look on that infrastructure constitutes associate physical capital good direct and indirect to economic growth. This research utilize analisis's method bifilar linear regression and time series's data. Base estimation result is found that infrastructure publicing to have influence that signifikan and terhdap's positive Gross Domestic Product.
\end{abstract}

Key word : Infrastructure, PDB and Indonesia

\begin{abstract}
Abstrak
Penelitian ini bertujuan untuk mengukur seberapa jauh pengaruh infrastruktur publik seperti jalan raya, listrik, air bersih dan telepon serta seluler terhadap Produk Domestik Bruto di Indonesia. Penelitian ini mendasarkan pada teori pertumbuhan ekonomi klasik dan neoklasik yang menganggap bahwa infrastruktur merupakan modal fisik yang berhubungan baik langsung dan tidak langsung terhadap pertumbuhan ekonomi. Penelitian ini menggunakan metode analisis regresi linear berganda dan data time series. Berdasarkan hasil estimasi ditemukan bahwa infrastruktur publik memiliki pengaruh yang signifikan dan positif terhdap Produk Domestik Bruto.
\end{abstract}

Kata Kunci: Infrastruktur, PDB dan Indonesia

\section{PENDAHULUAN}

Sebagai sebuah negara berkembang, Indonesia terus berupaya untuk mensejahterakan rakyatnya. Bidang ekonomi adalah hal penting yang terus menerus diperhatikan oleh pemerintah. Secara umum tujuan negara dalam ekonomi makro adalah untuk mencapai stabilitas ekonomi, pertumbuhan ekonomi yang tinggi, Produk Domestik Bruto serta penganguran yang sedikit.

Pemerintah dalam rangka mencapai tujuan tersebut memerlukan berbagai faktor pendukung yaitu salah satunya yang penting adalah keberadaan infrastruktur. Dengan adanya infrastruktur yang baik diharapkan merangsang dunia usaha akan 
menanamkan modalnya dalam investasi langsung sehingga dapat mempertinggi pertumbuhan. Infrastruktur yang baik juga akan memberikan akses yang lebih luas untuk menikmati sumber daya.

Investasi Indonesia untuk infrastruktur sangat tidak memadai. Hal ini dapat dilihat dari semakin menurunnya investasi. Contohnya investasi infrastruktur dari 5-6 persen dari PDB sebelum tahun 1997 menjadi kurang dari 1-2 persen dari PDB pada 2000 dan tahun 2007 berada dalam kondisi stabil pada tingkat 3,4 persen dari PDB (Bank Dunia,2007:80).

Dalam hal indikator infrastruktur Indonesia mengalami penurunan dan posisi Indonesia tertinggal dari negara tetangga. Beban listrik yang besar terpusat di Pulau Jawa dan Bali, sementara di pulau-pulau besar lainnya mengalami kekurangan listrik yang sangat besar. Jalan raya perkotaan jalan raya sudah terlalu padat dan jalan bebas hambatan yang baru yang diharapkan akan membantu mendorong pertumbuhan ekonomi masih dalam tahap perencanaan.

Rasio penduduk yang memiliki akses terhadap air pipa sebenarnya sudah mengalami penurunan akibat penutupan sejumlah fasilitas dan karena pertumbuhan penduduk. Bagaimanapun, pada masa lalu Indonesia pernah mengungguli Thailand, Taiwan, China, dan Sri Lanka dalam Global Competitiveness Report's 1996 tentang Indeks Mutu Infrastruktur secara keseluruhan. Pada 2002, negara-negara ini telah mampu melampaui Indonesia (Bank Dunia,2007:80).

Kemunduran investasi masa lalu perlu ditanggulangi, maka dari itu pemerintah pada saat yang sama juga melakukan proyek-proyek besar yang baru untuk memenuhi permintaan yang semakin besar dan untuk terus mendorong pertumbuhan. Tentu saja hal ini memerlukan tambahan investasi yang cukup besar (diperkirakan tambahan sekitar 2 persen dari PDB, atau US\$6 milyar pertahun), dengan tujuan hanya untuk mencapai tingkat pertumbuhan sebelum krisis.

Sektor air bersih dan listrik yang sangat vital mengalami krisis. Kurangnya kapasitas dan daya listrik serta memburuknya layanan air pipa adalah akibat dari tingkat investasi yang rendah selama satu dekade.. Penyediaan sambungan kepada konsumen di wilayah 
Indonesia bagian timur yang memerlukan biaya lebih tinggi terkendala oleh tarif listrik yang seragam bersifat regresif dan tidak memberikan insentif (Bank Dunia,2007:81).

Berdasarkan uraian diatas maka masalah yang ingin diteliti dalam penelitian ini adalah bagaimana pengaruh infratruktur publik yang terdiri dari jalan, listrik, air dan telepon secara bersamasama dan secara parsial terhadap Produk Domestik Bruto di Indonesia?

American Society of Civil Engineers (ASCE) menganggap definisi yang lebih komprehensif infrastruktur ada pada laporan tahunan "Daftar Laporan Infastruktur Amerika ". Daftar ini memuat data infrastruktur untuk penerbangan, jembatan, bendungan, air minum, energi, tempat limbah berbahaya, jalur air bernavigasi, taman umum dan rekreasi, kereta api, jalan, sekolah, keamanan, limbah padat, jalur transit dan jalur air limbah. Sekali lagi, bagaimanapun, daftar laporan tidak menjelaskan mengapa sarana sarana itu dikelompokan dalam kategori infrastruktur (dalam Dixon dan Baldwin, 2008:17)
Definisi Casablanca (yang disepakati oleh ahli ekonomi) mengugkapkan bahwa secara umum bahwa infrastruktur publik adalah meliputi sektor sektor berikut: transportasi, komunikasi, air dan sanitasi, listrik dan gedung gedung (gedung sekolah, rumah sakit, pengadilan, penjara dan sebagainya).

Karateristik infrastruktur adalah Aset memiliki bentuk fisik dengan masa pakai yang panjang. Penciptaan aset memerlukan cukup periode persiapan pembangunannya. Aset memiliki sedikit pengganti dalam jangka pendek. Struktur aset mampu memperlancar aliran barang dan jasa dan tanpa asset akan terjadi gangguan dalam aliran persediaan barang dan jasa. Aset penting terutama karena asset berfungsi sebagai barang komplementer atau pelengkap terhadap barang dan jasa dalam faktor produksi. Memiliki ekternalitas positif yaitu daya manfaatnya dapat dinikmati pihak diluar pembuat infratruktur tersebut (Baldwin dan Dixon,2008:20).

Bank Dunia (dalam Wahyuni, 2009:20-21) mendefinisikan infrastruktur ekonomi, merupakan aset fisik yang 
diperlukan untuk menunjang aktivitas ekonomi baik dalam produksi maupun konsumsi final, meliputi public utilities (tenaga, telekomunikasi, air minum, sanitasi dan gas), public work (jalan, bendungan, kanal, saluran irigasi dan drainase) serta sektor transportasi (jalan, rel kereta api, angkutan pelabuhan, lapangan terbang dan sebagainya).

Pertumbuhan ekonomi suatu negara dapat tercermin dalam produktivitas suatu negara. Produktiktitas dalam arti sempit adalah “....jumlah barang dan jasa yang dihasilkan seorang pekerja per jam kerja...". Sedangkan untuk definisi produktivitas negara dapat dikatakan adalah jumlah barang dan jasa yang dihasilkan oleh seluruh penduduk negara itu secara agrregat. Menurut Mankiw (1997:173) produktivitas dipengaruhi oleh faktor-faktor sebagai berikut yaitu modal fisik, modal manusia, sumber daya alam, dan pengetahuan teknologis.

Salah satu bagian dari barang modal fisik adalah infrastruktur (Case dan Fair ,2004:330). Sebuah negara jika memiliki lebih banyak peralatan dan infrastruktur yang jumlahnya lebih banyak maka negara tersebut kemampuan berproduksinya akan lebih meningkat dan lebih banyak.

Penggambaran hubungan yang jelas antara kuantitas input yang digunakan dalam produksi dengan kuantitas input yang digunakan fungsi produksi (Mankiw,1997:178). Dalam model tersebut anggaplah bahwa Y menunjukan jumlah output, L melambangkan jumlah tenaga kerja, $\mathrm{K}$ menunjukan kuantitas modal fisik, $\mathrm{H}$ kuantitas modal manusia dan $\mathrm{N}$ adalah kuantitas sumber daya alam. Dengan demikian, kita bisa menulis $\mathrm{Y}=$ A F $(\mathrm{L}, \mathrm{K}, \mathrm{H}, \mathrm{N})$

Teori pertumbuhan Neo Klasik, permintaan masyarakat tidak menentukan laju pertumbuhan sebaliknya tergantung dalam pertumbuhan ekonomi tergantung kepada pertambahan penawaran faktorfaktor produksi dan tingkat kemajuan teknologi. Pandangan ini didasarkan pada asumsi perekonomian akan tetap mengalami tingkat kesempatan kerja penuh dan kapasitas barang-barang modal akan tetap sepenuhnya digunakan dari masa ke masa. Pertambahan faktor- faktor produksi dan tingkat kemajuan teknologi akan menjadi penentu sampai dimana perekonomian berkembang (Sukirno,2007:263-264). 
Dalam teori Neo Klasik rasio modal produksi dengan mudah mengalami perubahan. Kombinasi jumlah antara modal yang diperlukan dan tenaga kerja yang diperlukan dapat berubah sesuai dengan kuantitas produksi yang diinginkan. Apabila modal yang tersedia sedikit, maka tenaga kerja yang digunakan banyak sebaliknya apabila modal yang digunakan banyak, maka tenaga kerja yang digunakan sedikit. Dengan kata lain terdapat fleksibilitas yang menjamin kebebasan perekonomian dalam menentukan alokasi modal dan tenaga kerja (Raharja dan Manurung, 2005:148-150)

Teori pertumbuhan neoklasik mempunyai suatu persamaan yang umum untuk menjelaskan teorinya yaitu suatu persamaan yang dikembangkan oleh Charles Cobb dan Paul Douglas, yang secara lazim disebut fungsi produksi Cobb douglas. Fungsi tersebut dapat dituliskan secara berikut $\mathrm{Y}_{\mathrm{t}}=\mathrm{T}_{\mathrm{t}} \mathrm{K}^{\alpha}{ }_{\mathrm{t}} \mathrm{L}^{\beta}{ }_{\mathrm{t}}$, Dengan keterangan $Y_{t}=$ tingkat produksi tahun $\mathrm{t}, \mathrm{T}_{\mathrm{t}}=$ tingkat teknologi tahun $\mathrm{t}, \mathrm{K}_{\mathrm{t}}=$ jumlah modal kapital pada tahun $\mathrm{t} \mathrm{L}_{\mathrm{t}}=$ jumlah tenaga kerja pada tahun $\mathrm{t} \alpha=$ pertambahan produksi yang diciptakan oleh pertambahan satu modal $\beta=$ pertambahan produksi yang diciptakan oleh pertambahan satu unit tenaga kerja. Persaman diatas dapat diubah menjadi persamaan sebagai berikut $r_{y}=r_{r}+\alpha_{r k}+$ $\beta_{1}^{\mathrm{r}}$ dengan keterangan $\mathrm{r}_{\mathrm{y}}=$ tingkat pertambahan pendapatan nasional $r_{r}=$ tingkat pertambahan teknologi $\mathrm{rk}=$ tingkat pertambahan stok modal ${ }_{1}^{r}=$ tingkat pertambahan tenaga kerja

Dari persamaan diatas kita dapat menarik kesimpulan bahwa merujuk teori pertumbuhan klasik, laju pertumbuhan ekonomi negara tergantung kepada tingkat perkembangan teknologi, peranan modal dalam menciptakan pendapatan nasional (produksi marginal modal) dikalikan dengan tingkat perkembangan stok modal dan peranan tenaga kerja dalam menciptakan pendapatan nasional (produktivitas tenaga kerja) dikalikan dengan tingkat pertambahan tenaga kerja (Arsyad, 2004:60).

Teori pertumbuhan Harrod-Domar adalah teori pertumbuhan yang berpijak pada asumsi Keynes. Teori ini menyatakan bahwa penanaman modal mempunyai dua fungsi dalam perekonomian yaitu (i) untuk menambah kapasitas barang-barang modal dan (ii) untuk mempertinggi keseluruhan 
pengeluaran masyarakat. Fungsinya yang terpenting adalah untuk menambah keseluruhan pembelanjaan. Teori HarrodDomar menganggap bahwa rasio modal adalah tetap, maka keadaan tersebut dapat diartikan bahwa hanya terdapat satu gabungan tertentu modal dan tenaga kerja yang digunakan untuk menghasilkan sejumlah produksi tertentu. Perubahan dalam hal modal, tenaga kerja akan tergantung dari perubahan sejumlah produksi (Sukirno, 2007:264).

Teori pertumbuhan baru menjadi acuan karena relevansinya membahas pertumbuhan. Menurut Raharja dan Manurung (2004:150-152). Persaman Teori endogen digambarkan dengan $\mathrm{Y}=$ AK. Dalam persaman ini, A menggambarkan faktor yang mempengaruhi tehnologi, dan $\mathrm{K}$ adalah modal fisik dan modal manusia (phisycal and human capital). Dalam persamaan ini hal yang harus diperhatikan adalah tiada hasil yang menurun (diminishing return) atas capital dalam formula capital dalam formula tersebut. Hal ini menimbulkan akibat berupa kemungkinan kesimpulanya bahwa investasi dalam modal manusia dan fisik dapat menghasilkan penghematan eksternal dan peningkatan produktivitas yang melebihi penghasilan yang cukup untuk menutup diminishing returns.

Lebih lanjut tentang kesimpulan itu maka investasi yang menghasilkan penghematan eksternal menyebabkan dihilangkanya a dari persamaan Solow, sehingga persamaan pertumbuhan neoklasik $\mathrm{Y}=A \mathrm{e}^{\mathrm{mt}} \mathrm{K}^{\mathrm{a}} \mathrm{L}^{1-\mathrm{a}}$ menjadi $\mathrm{Y}=$ $\mathrm{Ae}^{\mathrm{mt}} \mathrm{lK}$ dalam persamaan pertumbuhan ekonomi. Menurut Kuncoro (2006:73) persamaan ini, menunjukan bahwa bagi negara yang miskin modal manusia dan modal fisik yang sedikit sulit untuk menyamai tingkat pendapatan per kapita negara yang kaya kapital, walaupun memiliki tingkat tabungan nasional yang sama besar.

Todaro dan Smith (2006:174) menyatakan bahwa pertumbuhan ekonomi suatu negara salah satunya bergantung pada investasi komplementer negara dalam sumber daya manusia (pendidikan), infrastruktur atau riset dan pengembangan. Kesimpulan ini diambil Todaro dan Smith berdasarkan model teori pertumbuhan endogen. Model endogen yang dimaksud Todaro dan Smith menggunakan formulasi $\mathrm{Y}=\mathrm{AK}$. Penjelasannya yaitu bahwa produksi 
dipengaruhi oleh $\mathrm{K}$ yang mewakili modal fisik dan modal manusia serta A yang mencerminkan tehnologi. Teori pertumbuhan baru menyarankan peran aktif kebijakan publik dalam merangsang pembangunan ekonomi melalui investasi langsung maupun tidak langsung maupun tidak langsung dalam pembentukan sumber daya dan mendorong investasi swasta asing dalam berbagai industri padat-pengetahuan sepeti industri perangkat lunak dan telekomunikasi. Berdasarkan uraian diatas menyatakan bahwa modal fisik yang dimaksud adalah salah satunya merupakan infrastrukur.

Menurut Garmendia dkk (2004:04), hubungan antara jasa infrastruktur, pertumbuhan ekonomi dan hasil-hasil sosial seperti bekerjanya Millennium Development Goals melalui saluransaluran yang ganda seperti yang dilukiskan di dalam gambar 2.1. Kontribusi dari jasa seperti air, sanitasi , transportasi dan energi secara langsung rumah tangga manfaat dan dapat secara dramatis memperbaiki kesejahteraan mereka.

Banyak dari manfaat infrastruktur kepada perusahaan di Prancis, sebagai contoh, bahwa diagram input output mengungkapkan perusahaan perusahaan mengkonsumsi dua pertiga dari semua jasa prasarana (Prud'homme dalam Garmendia, et al., 2004:04). Jadi, dengan demikian saluran perusahaan akan menurunkan biaya-biaya dan, yang paling penting, peluang pasar diperluas (terutama melalui telekomunikasitelekomunikasi dan pengangkutan). Laba yang hasilnya di dalam daya saing dan produksi adalah apa yang dihasilkan di dalam pertumbuhan ekonomi dan pada akhirnya kesejahteraan.

Pada gambar 1. menunjukan adanya keterkaitan antara persediaan infrastruktur dengan pertumbuhan ekonomi. Infrastruktur secara tidak langsung akan mempengaruhi pertumbuhan ekonomi melalui jalur rumah tangga (melalui peningkatan kesejahteraan) dan perusahaan (melalui penurunan biaya dan perluasan pasar) yang nantinya akan berpengaruh secara bersama-sama terhadap pertumbuhan ekonomi.

Tinjauan Penelitian terdahulu, penelitian yang dilakukan oleh Cecilia Briceño-Garmendia, Antonio Estache, dan Nemat Shafik berjudul 


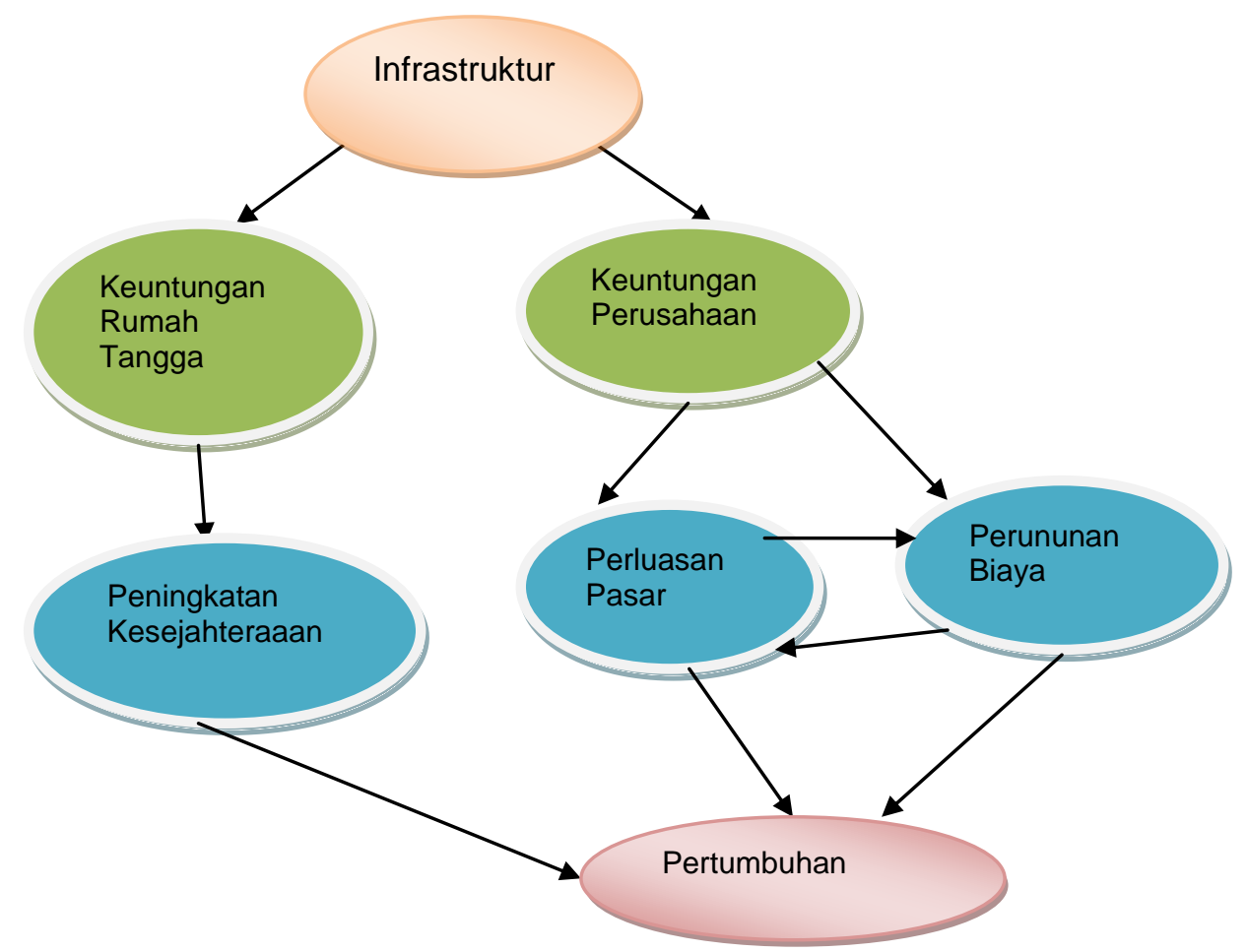

Sumber: Prud'homme dalam Garmendia, et al. (2004:04).

Gambar 1 : Diagram bagaimana infastruktur mempengaruhi pertumbuhan ekonomi

Infrastructure Services in modal tetap fisik dan modal manusia Developing Countries: Access, Quality, yaitu jumlah penduduk yang masuk Costs and Policy Reform. Penelitian ini sekolah tingkat menengah. Dengan menggunakan data negara berkambang. penambahan variabel independent yang Kesimpulannya penelitian ini pengaruh bukan infrastruktur maka akan infastruktur terhadap pertumbuhan ekonomi adalah positip dan signifikan (Garmendia,et al.,2004:17). Hal ini menunjukan tingkat pengaruh yang lebih kecil karena Garmendia menggunakan model berdasarkan persamaan Cobb Douglas, persamaan ini memperhitungkan modal fisik yang dipresentasikan dengan jumlah bruto mulai 1960-2000 dengan menggunakan 
data panel. Penelitian ini menyimpulkan bahwa pertumbuhan ekonomi secara positip dan signifikan dipengaruhi oleh persediaan infrasruktur, yaitu bahwa pertumbuhan ekonomi secara positip dipengaruhi oleh faktor keberadaan kepadatan jalan per kilometer kuadrat dan jalur kereta api berepengaruh secara signifikan terhadap pertumbuhan ekonomi pada negara negara seperti Argentina, Korea dan Taiwan.

Hasil lainnya adalah pertumbuahan ekonomi secara positip tetapi tidak signifikan dipengaruhi oleh infrastruktur pembangkit kapasitas listrik dan kesimpulan bahwa pertumbuhan ekonomi secara negatif tetapi tidak signifikan dipengaruhi oleh infrastruktur jaringan sanitasi pengakut air. Kemudian bahwa pertumbuhan ekonomi secara positip dan signifikan dipengaruhi oleh persediaan infrastuktur telekomunikasi (Calderon dan Serven ,2004:17-18,25,32-34).

Penelitian berjudul How Relevant Is Infrastructure to Growth inEast Asia?. Penelitian ini ditulis oleh Kalpana Seethepalli, Maria Caterina Bramati dan David Veredas. Penelitian mengemukakan persediaan infarstruktur secara jelas dapat menjelaskan pertumbuhan ekonomi. Penelitian menggunakan teori persamaan Solow yang mengikutsertakan modal manusia dan fisik sedangkan model yang kedua yaitu persamaan pengaruh infrastruktur yang telah dibuat persmaaan log. Hasil selanjutnya mengemukakan persediaan infarstruktur transportasi secara jelas dapat menjelaskan pertumbuhan ekonomi.

Sedangkan infrastruktur listrik juga berpengaruh terhadap pertumbuhan ekonomi. Hal ini dapat dilihat dari nilai Rsqurae yang mencapai $94 \%$ yaitu dengan variabel depedent pertumbuhan produk domestic bruto perkapita dan variabel independent yaitu keberadaan listrik. Penelitian menggunakan teori persamaan Solow yang mengikutsertakan modal manusia dan fisik sedangkan model yang kedua yaitu persmaan pengaruh infrastruktur yang telah dibuat persamaaan log. Sedangkan untuk telepon dapat diwakili oleh hasil penelitian yang menyatakan bahwa persediaan infarstruktur komunikasi secara jelas dapat menjelaskan pertumbuhan ekonomi (Seethepali,et al. ,2008:10,12,17,18,22).

Penelitian yang dilakukan Paul Noumba Um ,Stéphane Straub Charles 
Vellutini dari Bank Dunia yang berjudul Infrastructure and Economic Growth in the Middle East and North Africa dipublikasikan pada Oktober 2009. Penelitian ini menggunakan data dari negara-negara Timur Tengah dan Afrika Utara meliputi 20 negara serta menggunakan data panel. Kesimpulanya penelitian ini menyatakan bahwa infasrtuktur jalan, listrik, air dan telepon mampu menjelaskan faktor pertumbuhan ekonomi tetapi masih dipengaruhi oleh perubahan struktur perekonomian. (Um et al. ,2009:4,11,20,23).

Penelitian yang ditulis oleh Balázs Égert,Tomasz Koźluk dan Douglas Sutherland yang diberi judul Infrastructure and growth: Empirical evidence menegaskan bahwa Investasi di dalam jaringan infrastruktur dapat menaikkan tingkat pertumbuhan ekonomi jangka panjang di negara-negara OECD. Penelitian Egert menggunakan metode analisis estimasi time-series tahunan pada negara yang tergabung dalam OECD (Egert et al.,2009:01)

Penelitian yang ditulis oleh Balázs Égert,Tomasz Koźluk dan Douglas Sutherland yang diberi judul Infrastructure and growth: Empirical evidence menegaskan bahwa Investasi di dalam jaringan infrastruktur dapat menaikkan tingkat pertumbuhan ekonomi jangka panjang pada negara negara. Analisis penelitian ini menjelaskan hubungan yang empirik antara infrastruktur dan pertumbuhan ekonomi. Analisis time-series mengungkapkan suatu hal positip estimator dari investasi infrastruktur di pertumbuhan model Bayesian pemerataan kemundurankemunduran pertumbuhan potongan mengkonfirmasikan infrastruktur itu investasi di dalam telekomunikasitelekomunikasi dan sektor-sektor kelistkrikan mempunyai suatu kecenderungan pengaruh positip di pertumbuhan yang jangka panjang (tidak jaringan jalan kereta api dan jalan) (Egert,et al.,2009:21,39)

Pada infrastruktur transportasi pengaruh postif yang kuat dari jalan perkapita terhadap GDP perkapita dan dalam jangka pendek dapat diidentifikasi untuk negara Inggris dan Selandia Baru. Alternatif spesifikasi yang lain juga menunjukan pengaruh yang positip yaitu untuk negara Australia dan Portugal. Jika variabel dikombinasikan dengan jalan motor maka dapat ditemukan efek 
positip pengaruh infrastruktur konunikasi terhadap GDP perkapita pada negara Austria, Spanyol, dan Jepang. Selain penemuan diatas juga ditemukan pula pengaruh negatif infratsruktur transportasi terhadp gdp perkapita yaitu pada negara Prancis, Yunani ,Spanol dan Belanda (Egert,et al.,2009:20).

Penelitian ini menyimpulkan bahwa infrastruktur telepon berpengaruh positip secara signifikan pada negara Austria, Spanyol, Yunani ,Italia, Norwegia dan Islandia. Meskipun demikian penelitian juga menunjukan pengaruh negatif seperti pada negara Australia, Inggris, Irlandia dan Selandia Baru (Egert,2009:21).

Penelitian berjudul The Contribution of Infrastructureto Aggregate Output ditulis oleh David menyatakan bahwa infrastruktur rute transportasi (panjang jalan aspal dan jalur kereta api) per pekerja secara tidak signifikan mempengaruhi produktivitas pekerja hal ini terjadi menurut Canning karena faktor tersebut merupakan bagian dari seluruh infestasi pada infrastruktur dan akan menjadi biaya yang harus dikeluarkan sehingga pada gilirannya memberikan dampak negatif dalam meningkatkan marginal produktifitas pekerja (Canning,1999:12).

Penelitian berjudul The Contribution of Infrastructureto Aggregate Output ditulis oleh David Canning menyatakan bahwa infrastruktur kapasitas pembangkit listrik per pekerja secara tidak signifikan dan kecil untuk mempengaruhi produktivitas pekerja hal ini terjadi menurut Canning karena faktor tersebut merupakan bagian dari seluruh infestasi pada infrastruktur dan akan menjadi biaya yang harus dikeluarkan sehingga pada gilirannya memberikan dampak negatif dalam meningkatkan marginal produktifitas pekerja (Canning,1999:12).

Penelitian

berjudul

The Contribution of Infrastructureto Aggregate Output ditulis oleh David Canning menyatakan bahwa infrastruktur telepon per pekerja secara positip dan signifikan mempengaruhi produktivitas pekerja (Canning,1999:12).

Penelitian yang dilakukan oleh Surya Tarmizi Kasim yang kesimpulannya adalah bahwa kinerja infrastruktur listrik berpengaruh secara positip dan signifikan terhadap produk domestik bruto (Kasim,2006:01). 
Literatur empiris yang lebih baru, kebanyakan dalam konteks data panel lintas negara, telah memastikan kontribusi output yang signifikan pada sejumlah besar negara dan oleh Demetriades and Mamuneas (2000) dalam Calderon dan Serven (2004:04) menggunakan data OECD. Roller dan Waverman (2001) dalam Calderon dan Serven (2004:04) juga menemukan efek output yang besar dari infrastruktur telekomunikasi dalam negara industri, dalam kerangka kerja bahwa dapat dilakukan pengendalian endogeneity akumulasi infrastruktur. Hasil yang sama untuk jalan raya dilaporkan oleh Fernald (1999) dalam Calderon dan Serven (2004:04) menggunakan data industri untuk Amerika Serikat.

Calderon and Serven (2004:04), pada penelitan mereka tahun 2003 menyajikan analisa empiris yang hampir sama dengan yang menjadi fokus di Amerika Latin. Menggunakan estimasi GMM teknologi produksi Cobb-Douglas yang diperoleh dari seperangkat data panel lintas negara yang besar, Calderon menemukan kontribusi output yang positip dan signifikan dari tiga tipe aset infrastruktur-telekomunikasi, transport dan daya. Estimasi produktivitas marginal dari aset-aset ini secara signifikan melebihi modal noninfrastruktur. Pada basis estimasi itu, Calderon menduga bahwa porsi utama kesenjangan output per-kapita yang terbuka antara Amerika Latin dan Asia Timur selama 1980-an dan 1990-an dapat dilacak balik pada pelambatan akumulasi infrastruktur Amerika Latin pada tahuntahun itu.

Lopez dalam Calderon dan Serven (2004:04) adalah menilai kontribusi infrastruktur pada pertumbuhan dan distribusi pendapatan. Dalam kerangka kerja panel dan pengendalian untuk penyebab reversi yang mungkin terjadi, Lopez menemukan bahwa infrastruktur meningkatkan pertumbuhan dan mengurangi ketimpangan pendapatan.

Beberapa makalah melakukan lebih dari pengukuran pengeluaran infrastruktur dan stok infrastruktur, dan mempertimbangkan isu efisiensi infrastruktur. Hulten menemukan bahwa perbedaan dalam penggunaan sumber daya infrastruktur yang efektif menjelaskan seperempat perbedaan pertumbuhan antara Afrika dan Asia Timur, dan lebih dari 40 persen 
perbedaan pertumbuhan antara negara dengan pedapatan rendah dan tinggi. Esfahani and Ramirez dalam Calderon dan Serven (2004:04) melaporkan pertumbuhan yang signifikan sebagai efek dari infrastruktur dalam seperangkat data panel yang besar dimana kontribusi infrastruktur dipengaruhi oleh faktor institusional.

Berdasarkan kajian teoritis seperti yang telah diuraikan maka berikut ini dikemukakan kerangka konseptual yang berfungsi sebagai penuntun, alur pikir dan sekaligus sebagai dasar dalam merumuskan hipotesis.

Keterkaitan antara infrastruktrur dan pertumbuhan ekonomi tidak terlepas dari fungsi dari infrastruktur sebgai enabler kegiatan ekonomi. Infrastruktur mempunyai manfaat menggerakan berbagai sektor perkenonomian karena dianggap sebagai social overhead capital (Hirchman dalam Yanuar dalam Permana, 2009:11).

\section{METODE PENELITIAN}

Penelitian ini merupakan penelitian penjelas (explanatory research) karena menjelaskan hubungan kausal antara variabel tertentu melalui pengujian hipotesis. Pendekatan yang digunakan dalam penelitian ini adalah dengan metode kuantitatif. Metode kuantitatif adalah suatu metode yang menggunakan data berupa angka nominal dan statistika untuk menjawab tujuan penelitian. Lingkup penelitian ini meliputi wilayah Indonesia. Waktu penelitian adalah mulai dari tahun 1979 sampai tahun 2007.(data termasuk Timor Leste sampai tahun 1999).

Untuk memperjelas tentang variabel yang digunakan maka dipandang perlu memberi keterangan sebagai berikut. Bahwa variabel bebas diwakili oleh Produk Domestik Bruto. Perkapita dengan harga konstan tahun 2000 dalam satuan dollar Amerika Serikat. Variabel keberadaan jalan diwakili oleh kepadatan jalan, variabel listrik diwakili oleh konsumsi listrik per kapita, variabel air diwakili air yang disalurkan per kapita, variabel telpon diwakili oleh jumlah sambungan telepon per 100 orang dan jumlah pemakai telepon dan telepon genggam per 100 orang.

Variabel panjang jalan per luas wilayah (road density) (X1) adalah perbandingan atau rasio antara panjang jalan total (baik yang diaspal dan tidak 
diaspal) dengan luas daratan di seluruh Indonesia Kepadatan ini diukur menggunakan satuan kilometer per kilometer persegi. Data ini diperoleh dari membagi total jalan tiap tahun mulai tahun 1979 sampai 2007 dengan luas wilayah daratan Indonesia.

Variabel konsumsi listrik per kapita (X2) adalah perbandingan total keberadaan lisrik dengan jumlah penduduk. Total keberadaan listrik dihitung berdasarkan produksi tenaga listrik dari pembangkit tenaga listrik baik yang berasal proses trasmisi ataupun dari tenaga panas, tenaga lsitrik yang hilang diserap pada saat didistribusikan dan tenaga listrik yang hilang diserap ketika ditransformasi ke bentuk lain ataupun bentuk tenag panas. Variabel ini mengunakan Jumlah tenaga listrik total di Indonesia dibagi jumlah penduduk sehingga ditemukan konsumsi listrik per kapita. Variabel konsumsi listrik per kapita menggunakan kwh percapita / (kilowatthours percapita). Variabel ini dihitung pertahun mulai tahun 1979 sampai 2007.

Variabel air yang disalurkan per kapita (X3) adalah perbandingan antara total air yang didistribusikan Perusahaan
Air Minum (PAM) di seluruh Indonesia kepada para pelangganya dengan jumlah penduduk di Indonesia. Variabel ini menggunakan satuan meterkubik per kapita dan dihitung pertahun mulai tahun 1979-2007.

Variabel jumlah sambungan telepon per 100 orang (X4) adalah perbandingan atau rasio antara jumlah sambungan telepon dengan tiap tiap 100 penduduk di Indonesia. Sambungan Telepon yaitu suatu jalur yang menghubungkan antara alat transmisi pada telepon pelanggan kepada jaringan telepon publik atau jaringan bersama melalui pusat alat transmisi dalam daerah tertentu termasuk meliputi jasa jaringan digital dan pengguna wireless. Satuan variabel ini menggunakan satuan SST (Satuan Sambungan Telepon).

Metode yang digunakan dalam penelitian ini adalah metode kuantitatif dengan menggunakan alat ekonometrika melalui pengestimasian Engle-Granger Cointegration dan Error Correction Model (ECM) untuk mengetahui faktorfaktor yang mempengaruhi impor susu sebagai permasalahan yang mendegradasi daya saing susu domestik pada jangka 
panjang maupun pendek yang diestimasi dengan persamaan searah import demand. Engle-Granger Cointegration Kointegrasi adalah suatu hubungan jangka panjang (equilibrium) antara variabel-variabel yang tidak stasioner dan residual dari kombinasi linier tersebut harus stasioner, sehingga dapat mengetahui kemungkinan terjadinya kestabilan jangka panjang antara variabelvariabel yang digunakan.. Engle-Granger Cointegration sebetulnya menggunakan metode Augmented Dickey-Fuller (ADF) yang terdiri dari dua tahap. Tahap pertama dilakukan dengan meregresikan persamaan variabel dependen dengan variabel independen volume impor susu Indonesia diregresikan dengan produksi susu domestik, harga riil susu impor, harga riil susu domestik, nilai tukar riil Rupiah, dan pendapatan per kapita masyarakat) kemudian didapatkan residual (u) dari persamaan tersebut. Tahapan kedua dilakukan dengan menggunakan Augmented Dickey Fuller Test terhadap u. Jika signifikan, maka variabel $\mathrm{u}$ adalah stasioner. Artinya meskipun variabel-variabel yang digunakan tidak stasioner, namun dalam jangka panjang variabel-variabel tersebut cenderung menuju pada keseimbangan. Oleh karena itu, kombinasi linier dari variabel-variabel ini disebut regresi kointegrasi dan parameter-parameter yang dihasilkan dari kombinasi tersebut dapat disebut sebagai cointegrated parameters atau koefisien-koefisien jangka panjang (Thomas, 1997).

Enders (2004) menyatakan bahwa Engle-Granger Cointegration memiliki beberapa kelemahan, yaitu: Tidak memiliki prosedur sistematis untuk mengestimasi vektor kointegrasi berganda ( multiple cointegration) secara terpisah. Prosedur estimasi Engle-Granger Cointegration terdiri atas dua tahap yang saling berkaitan. Tahap pertama adalah menghasilkan residual. Tahap kedua adalah mengestimasi regresi, akibatnya koefisien yang diperoleh melalui estimasi regresi menggunakan residual dari regresi lainnya. Hal ini mengakibatkan error yang dihasilkan pada tahap pertama dilanjutkan pada tahap kedua. Model yang digunakan dalam penelitian ini adalah: GDP Percapita $=\beta_{0}+\beta_{1} \operatorname{Jalan}_{\mathrm{t}}+$ $\beta_{2}$ Listrik $_{\mathrm{t}}+\beta_{3}$ Telepon $_{\mathrm{t}}+\mu_{\mathrm{t}}$.GDP Percapita $_{\mathrm{t}}=$ GDP per kapita harga konstan tahun 2000 pada periode $\mathrm{t}$. $\mathrm{Jalan}_{\mathrm{t}}=$ road density pada periode $\mathrm{t}$. Listrik $_{\mathrm{t}}=$ konsumsi 
listrik per kapita pada periode $\mathrm{t}$ Telepon $\mathrm{t}=$ sambunagn telepon per 100 orang pada peiode $\mathrm{t} \mu_{\mathrm{t}}=$ distribusi error periode $\mathrm{t}$. Error Correction Model

Hasil estimasi pada pengujian akarakar unit dan kointegrasi dapat digunakan untuk mengestimasi model dengan menggunakan Error Correction Model (ECM), seperti yang tertera dalam Persamaan berikut ini : DGDP Percapita ${ }_{t}$ $=\beta_{0}+\beta 1$ DJalant $+\beta 2$ DListrikt + $\beta 3 \mathrm{DTelepont}+\mathrm{D} \gamma \mu_{\mathrm{t}-1}+e_{t}, \mathrm{D}=$ pembedaan pertama (first difference) GDP Percapita $_{\mathrm{t}}=$ GDP per kapita harga konstan tahun 2000 pada periode $\mathrm{t} \mathrm{Jalan}_{\mathrm{t}}$ = road density pada periode $\mathrm{t}$, Listrik $_{\mathrm{t}}=$ konsumsi listrik per kapita pada

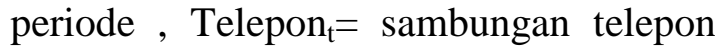
per 100 orang pada peiode $t, \gamma=$ eror correction term $\mu_{\mathrm{t}}=\beta_{0}-\beta_{1} \operatorname{Jalan}_{\mathrm{t}}-$ $\beta_{2}$ Listrik $_{\mathrm{t}}-\beta_{3}$ Telepon $_{\mathrm{t}}, e_{t}=$ Error distribunce periode $\mathrm{t}$

\section{PEMBAHASAN}

Indonesia merupakan negara berkembang dan memiliki banyak indikator perekonomian salah satunya adalah pertumbuhan ekonomi. Produk Domestik Bruto (PDB) atas dasar harga konstan berfungsi menunjukan tingkat peningkatan atau penurunan output perekonomian dari tahun ke tahun dan telah mengesampingkan faktor inflasi (kenaikan harga bersama secara terus menerus). Pada tahun 1980 Produk Domestik Bruto mencapai 54.101.010.733 US\$ sedangkan pada tahun 2008 mencapai 2.33097 x $10^{11}$ US\$ dan bermakna bahwa Produk Domestik Bruto terus mengalami kenaikan. Kenaikan Produk Domestik Bruto berasal dari aktivitas ekonomi mengalami fluktuasi secara jangka panjang disebabkan oleh pengaruh faktor kondisi politik dan ekonomi. Pada kurun waktu 1997-1998 Indonesia mengalami kontraksi pada perekonomian yang berpengaruh kepada seluruh sektor ekonomi yang lainya, bahkan pertumbuhan ekonomi Indonesia mencapai penurunan sebesar $-11,08 \%$. Penurunan ini menimbulkan penuruan produk domestic bruto ditunjukan oleh grafik yang agak curam pada Gambar 4.1. Pemulihan akibat guncangan krisis baru bisa dipulihkan pada tahun 2000 dua tahun setelah krisis moneter terjadi. Kondisi stabil dan meningkat terjadi pada pertumbuhan ekonomi Indonesia pada 
tahun setelah tahun 2000 sampai dengan tahun 2007.

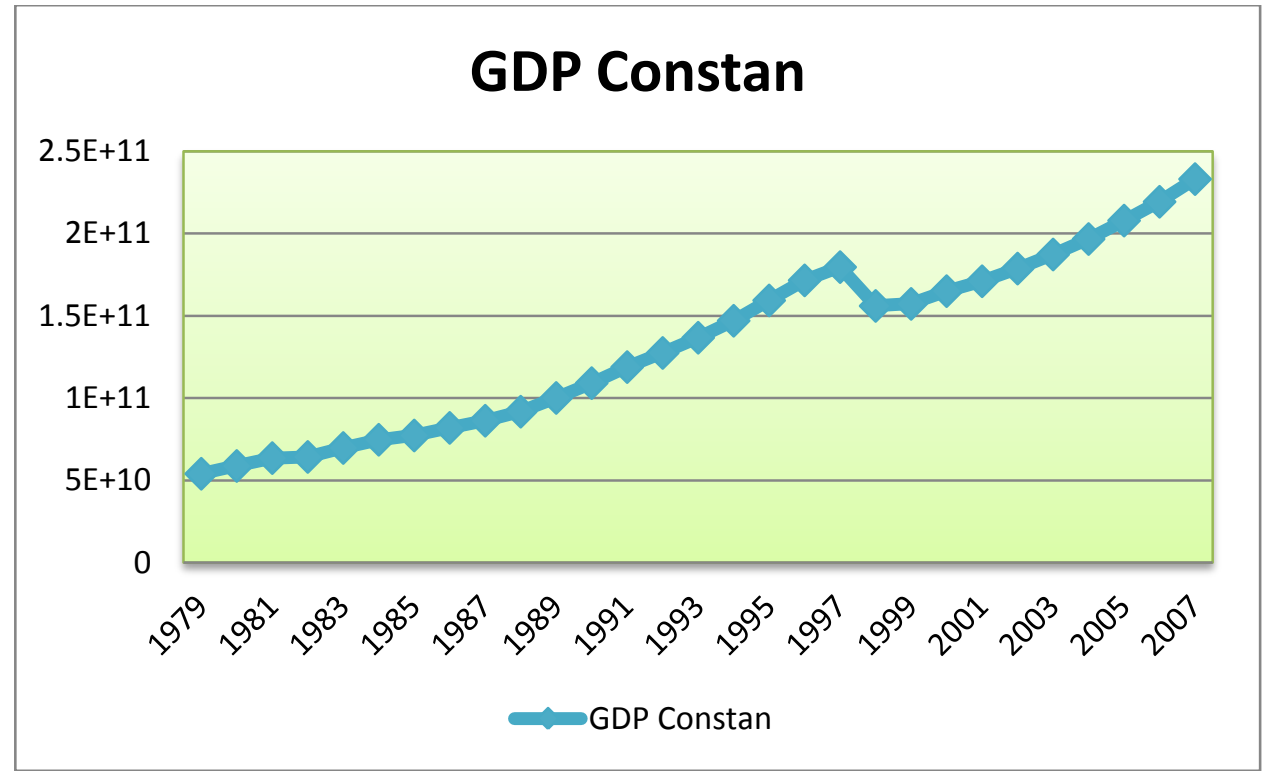

Gambar 2.: Produk Domestik Bruto (PDB) Indonesia atas harga konstan tahun 2000. Tahun 1979 - 2007 (\%)

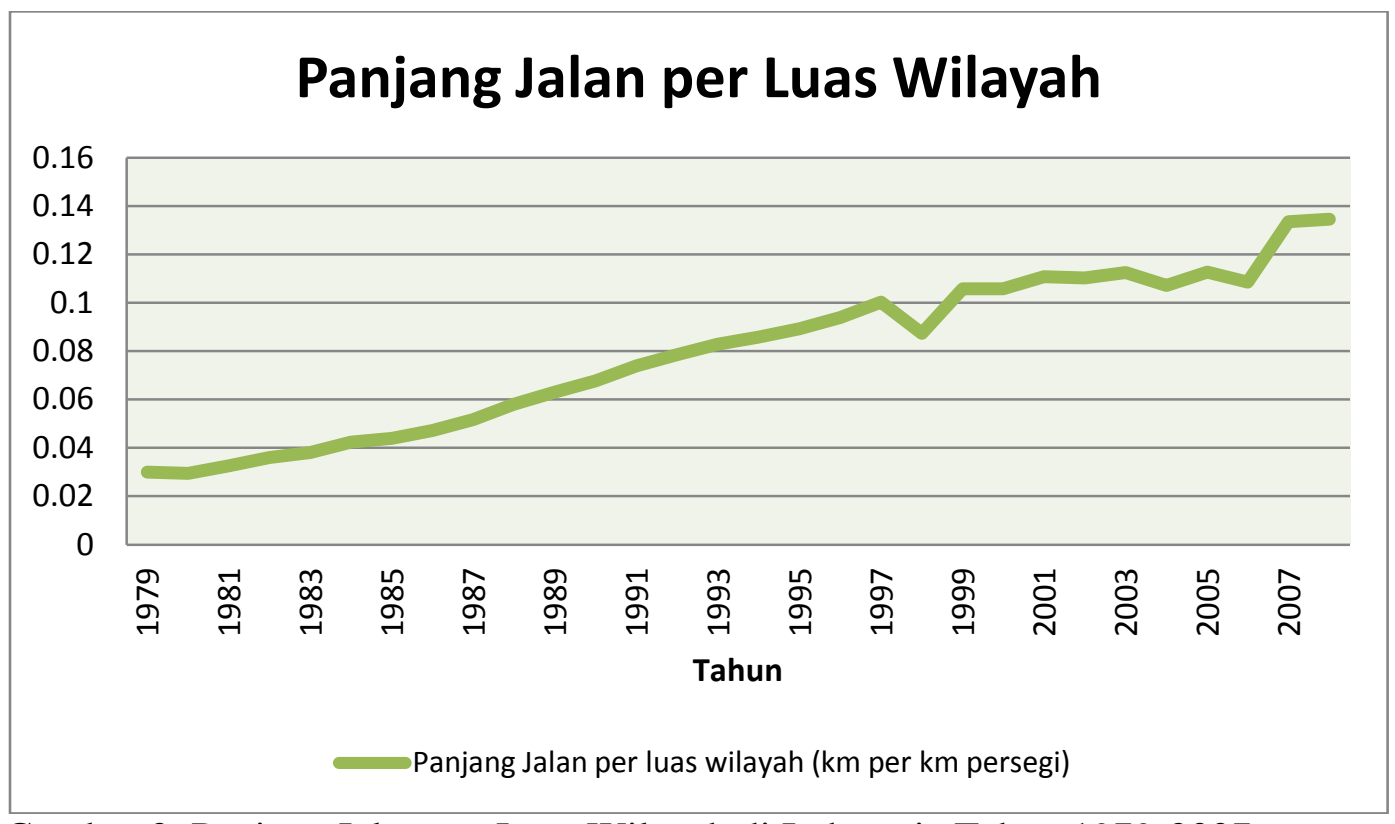

Gambar 3: Panjang Jalan per Luas Wilayah di Indonesia.Tahun 1979-2007 Sumber : data diolah 
Pada gambar 3. diperlihatkan panjang jalan per luas wilayah di Indonesia, dapat ditarik kesimpulan bahwa panjang jalan per luas wilayah terus mengalami peningkatan. Pada tahun 1980 panjang jalan per luas wilayah mencapai 0.02939763 sedangkan pada tahun 1995 mencapai $0.08920768 \mathrm{~km}$ per $\mathrm{km}^{2}$ dan terus meningkat pada tahun 2007 telah mencapai $0.13458236 \mathrm{~km}$ per $\mathrm{km}^{2}$. Rata rata pertumbuhan panjang jalan per tahun dari tahun 1980 sampai 1995 adalah $7,41 \mathrm{~km}$ per $\mathrm{km}^{2}$ per tahun sedangkan rata rata pertumbuhan panjang jalan per luas wilayah dari tahun 1995 sampai 2007 adalah sebesar 17,5 $\mathrm{km}$ per $\mathrm{km}^{2}$ per tahun

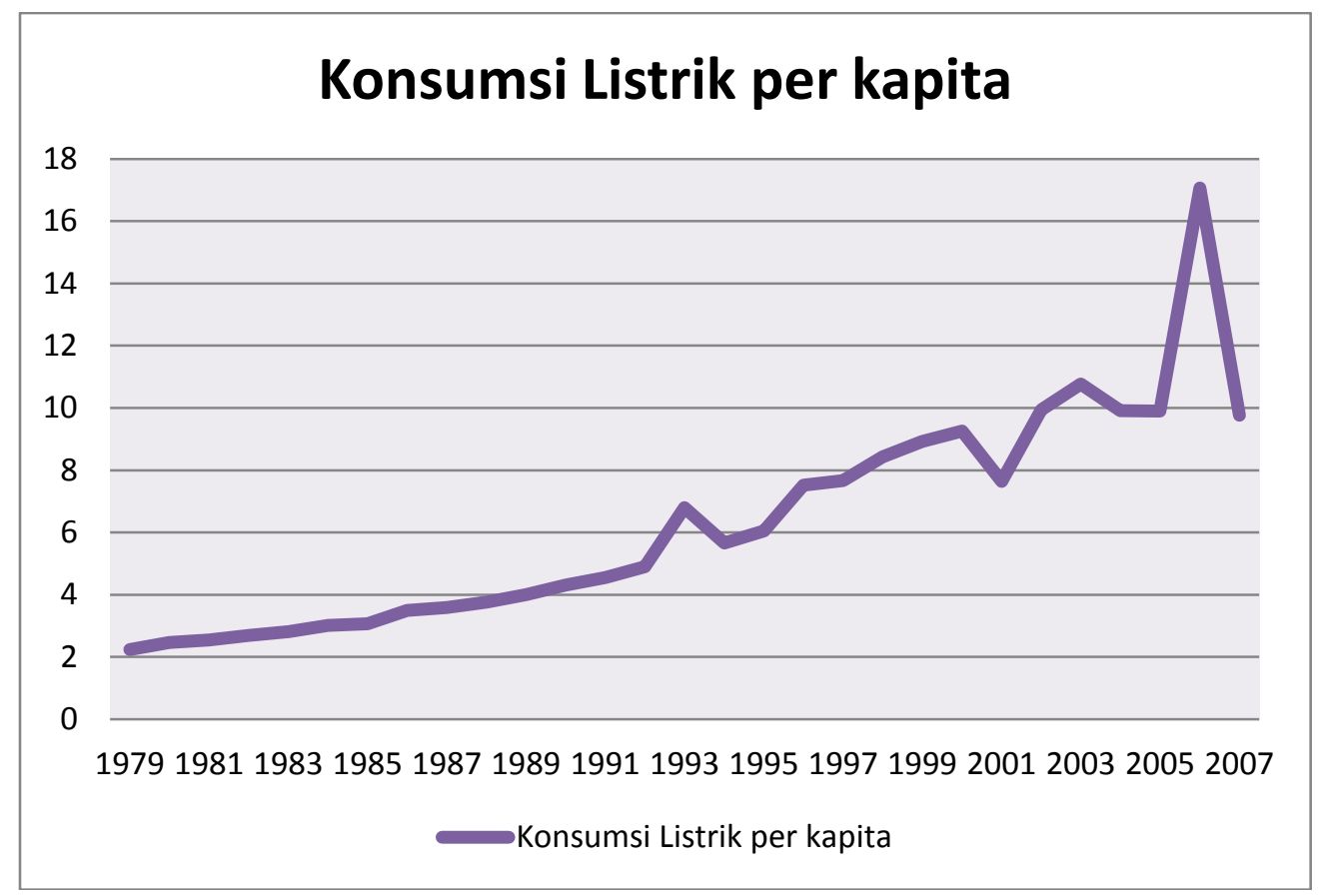

Gambar 4: Konsumsi Listrik per kapita di Indonesia.Tahun 1979-2007 Sumber: Bank Dunia

Berdasarkan gambar 4. per kapita mencapai $2.462784915 \mathrm{kwh}$ diperlihatkan konsumsi lsitrik per kapita per kapita sedangkan pada tahun 1995 di Indonesia, dapat ditarik kesimpulan mencapai 6.046954918 kwh per kapita bahwa konsumsi listrik per kapita terus dan terus meningkat pada tahun 2007 mangalami peningkatan dari tahun ke tahun. Pada tahun 1980 konsumsi listrik

telah mencapai $9.767765861 \mathrm{kwh}$ per kapita. Rata rata pertumbuhan konsumsi 
lsitrik per kapita tahun dari tahun 1980 sampai 1995 adalah 3.842005 kwh per kapita per tahun sedangkan rata rata pertumbuhan konsumsi listrik per kapita dari tahun 1995 sampai 2007 adalah sebesar 9.448233 kwh per kapita per tahun.

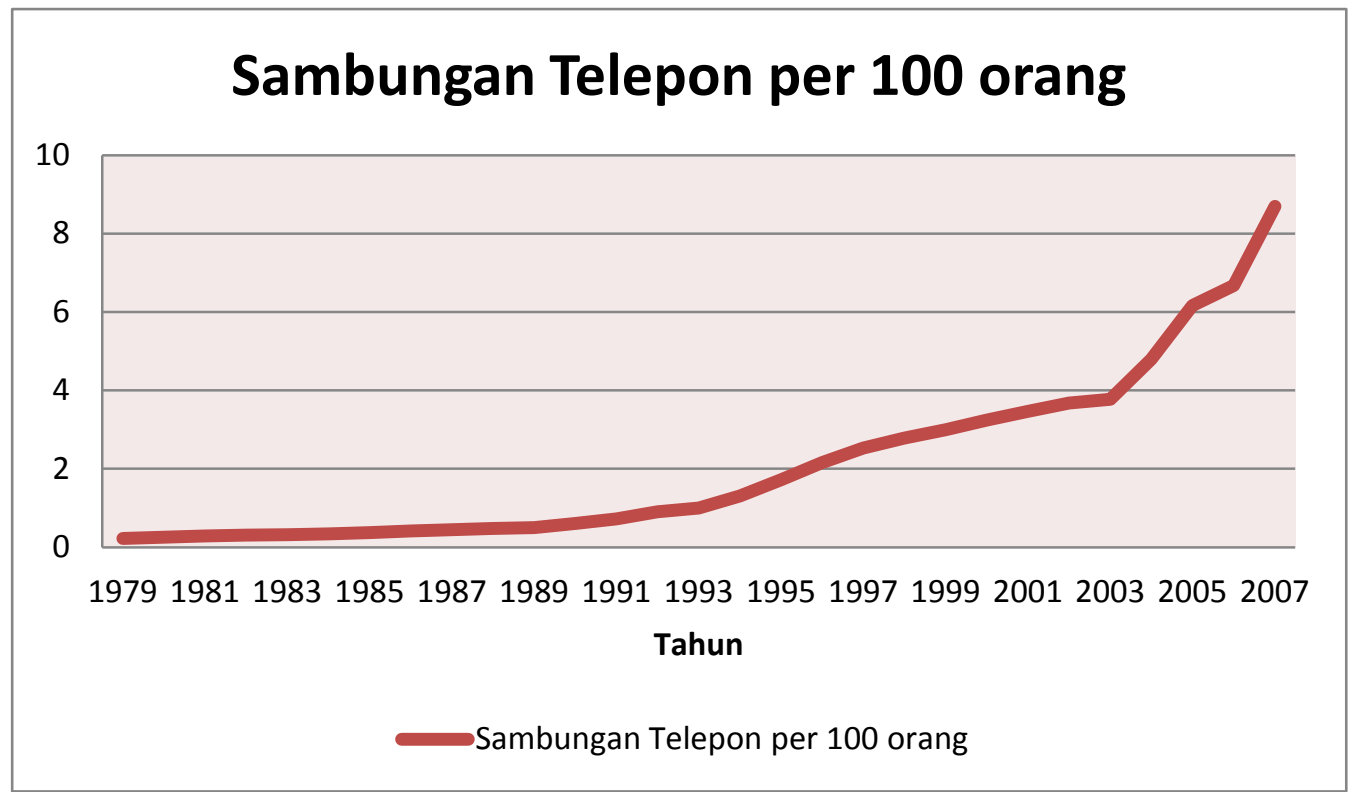

Gambar 5: Jumlah Sambungan Telepon per 100 orang.Tahun 1979-2007 Sumber: Bank Dunia

Mengutip gambar 5. diperlihatkan jumlah sambungan telepon per 100 orang penduduk di Indonesia, dapat ditarik kesimpulan bahwa jumlah sambungan telepon per 100 orang terus mangalami peningkatan dari tahun ke tahun. Pada tahun 1979 jumlah sambungan telepon per 100 orang mencapai 0.221022 SST sedangkan pada tahun 1994 mencapai 1.304985659 SST dan terus meningkat pada tahun 2006 telah mencapai 6.677399146 SST. Rata rata pertumbuhan jumlah sambungan telepon per 100 orang tahun dari tahun 1979 sampai 1994 adalah 0.529471 SST per tahun sedangkan rata-rata pertumbuhan jumlah sambungan telepon per 100 orang dari tahun 1994 sampai 2007 adalah sebesar 3.856217 SST per tahun.

Uji Stasioneritas Data deret waktu dikatakan stasioner jika menunjukan pola yang konstan dari waktu ke waktu. Adapun uji akar unit yang digunakan dalam penelitian ini adalah uji Augmented 
Dickey Fuller (ADF). Apabila nilai tstatistik ADF lebih kecil daripada nilai kritis MacKinnon, maka variabel tersebut tidak memiliki akar unit sehingga dikatakan stasioner pada taraf nyata tertentu. Hasil uji ADF untuk data time series setiap variabel pada tingkat level dapat dilihat pada Tabel 2 .

Tabel 1. Hasil Augmented Dickey Fuller pada Level

\begin{tabular}{cccccc}
\hline Variabel & Nilai ADF t & \multicolumn{3}{c}{ Nilai Kritis MacCinnon } & Keterangan \\
\cline { 3 - 5 } & stastistic & 1 persen & 5 persen & 10 persen & \\
\hline $\begin{array}{c}\text { GDP } \\
\text { percapita }\end{array}$ & 2.743196 & -3.679322 & -2.967767 & -2.622989 & $\begin{array}{c}\text { Tidak } \\
\text { Stasioner }\end{array}$ \\
\hline Jalan & 1.277955 & -3.689194 & -2.971853 & -2.625121 & $\begin{array}{c}\text { Tidak } \\
\text { Stationer }\end{array}$ \\
\hline Listrik & 1.871147 & -3.752946 & 2.998064 & -2.638752 & $\begin{array}{c}\text { Tidak } \\
\text { Stationer }\end{array}$ \\
\hline Telepon & 2.660034 & -3.752946 & -2.998064 & 2.638752 & $\begin{array}{c}\text { Tidak } \\
\text { Stsioner }\end{array}$ \\
\hline
\end{tabular}

Tabel 1. memperlihatkan bahwa susu domestik (PD), dan nilai tukar riil terdapat empat variabel yang tidak Rupiah (RER). Berdasarkan hal tersebut, stasioner pada level, yakni variabel volume impor susu (QM), volume maka kembali dilakukan pengujian Augmented Dickey Fuller Test lanjutan produksi susu domestik (QP), harga riil pada tingkat first difference Tabel 2. Hasil Uji Augmented Dickey Fuller pada First Difference

\begin{tabular}{cccccc}
\hline Variabel & \multirow{2}{*}{$\begin{array}{l}\text { Nilai ADF } \\
\text { stastistic }\end{array}$} & $\mathrm{t}$ & \multicolumn{2}{l}{ Nilai Kritis MacCinnon } & Keterangan \\
\cline { 3 - 5 } $\begin{array}{c}\text { GDP } \\
\text { percapita }\end{array}$ & -6.814129 & -3.689194 & -2.971853 & -2.625121 & Stasioner \\
\hline Jalan & -9.157320 & -3.689194 & -2.971853 & 2.625121 & Stasioner \\
\hline Listrik & -3.269750 & -4.416345 & -4.416345 & -3.248592 & Stasioner \\
\hline Telepon & -3.904237 & -4.440739 & -3.632896 & -3.254671 & Stasioner \\
\hline
\end{tabular}

Tabel 2. menunjukkan bahwa semua data yang digunakan dalam penelitian ini stasioner pada first difference.
Engle-Granger Cointegration Uji kointegrasi Engle-Granger digunakan untuk mengestimasi hubungan jangka panjang antara GDP per capita dengan 
jalan, listrik dan telepon. Tahap awal dari uji kointegrasi Engle-Granger adalah dengan meregresi persamaan OLS antara variabel dependen dan variabel independen. Kemudian setelah meregresi persamaan didapatkan residual dari persamaan tersebut. Uji ADF pada Tabel 3. Uji Augmented Dickey Fuller Persamaan Residual

\begin{tabular}{cccccc}
\hline \multirow{2}{*}{ Variabel } & Nilai ADF t & \multicolumn{3}{c}{ Nilai Kritis MacCinnon } & \multirow{2}{*}{ Keterangan } \\
\cline { 3 - 6 } & stastistic & 1 persen & 5 persen & 10 persen & \\
\hline ECT & -4.602184 & -3.689194 & -2.971853 & -2.625121 & Stasioner \\
\hline
\end{tabular}

Berdasarkan informasi yang tertuang dalam Tabel 3, diketahui bahwa nilai ADF $t$-statistic lebih kecil daripada nilai kritis MacKinnon pada taraf nyata 1 persen, 5 persen, maupun 10 persen, GDP_CAP_TAN=9.868366929e+0 $10 *$ JALAN + 786328852.1 * LISTRIK$1826072067 *$ TELEPON

Error Correction Model (ECM) digunakan untuk mengestimasi model dinamis jangka pendek dari variabel produk domestik bruto perkapita. Penggunaan metode estimasi ECM dapat menggabungkan efek jangka pendek dan jangka panjang yang disebabkan oleh fluktuasi dan time lag dari masing variabel independen (Thomas, 1997). Dalam penelitian ini, estimasi ECM untuk volume impor susu dilakukan dengan cara residual bersifat stasioner pada level atau I(0) sehingga dapat dikatakan bahwa variabel yang digunakan cenderung menuju keseimbangan pada jangka panjang walaupun pada tingkat level terdapat variabel yang tidak stasioner. 
Uji autokorelasi yang digunakan dalam penelitian ini adalah BreuschGodfrey Serial Correlation LM Test . Nilai probabilitas $(0,3238)$ yang lebih besar apabila dibandingkan dengan taraf nyata 10 persen menunjukkan bahwa tidak terdapat permasalahan autokorelasi dalam model persamaan tersebut.

Uji heteroskedastisitas yang digunakan dalam penelitian ini adalah

White Heteroscedasticity Test (no cross term). Probabilitas $O b s * R$-squared sebesar 0,64244 yang lebih besar dibandingkan taraf nyata 10 persen membuat model persamaan dinamis jangka pendek ECM terbebas dari problem heteroskedastisitas.

Analisis Pengaruh Infrastruktur Ekonomi terhadap Produk Domestik Bruto perkapita dalam jangka panjang : Tabel 5 : Hasil Estimasi Faktor-faktor yang Mempengaruhi Impor Susu pada Jangka Panjang

\begin{tabular}{lll}
\hline Variabel & Koefisien & Probabilitas \\
\hline Jalan & 3.659780 & 0,0011 \\
\hline Listrik & 4.052408 & 0,0004 \\
\hline Telepon & 4.052408 & 0,0000 \\
\hline
\end{tabular}

\section{PEMBAHASAN}

Variabel Panjang Jalan per Luas wilayah (X1) adalah perbandingan atau rasio antara panjang jalan total (baik yang diaspal dan tidak diaspal) dengan luas daratan di seluruh Indonesia. Variabel ini diukur menggunakan satuan kilometer per kilometer persegi. Data ini diperoleh dari membagi total jalan tiap tahun mulai tahun 1979 sampai 2007 dengan luas wilayah daratan Indonesia.

Sumber daya di daerah sulit berkembang disebabkan oleh infrastruktur yang kurang. Sebagai contoh, gambar 6. yang berbentuk Sactter graph mengambarkan hubungan panjang per luas wilayah dengan pendapatan per kapita propinsi propinsi di Indonesia. Data yang digunakan adalah sebelum terjadi krisis ekonomi. Untuk variabel panjang jalan per luas wilayah adalah panjang jalan Negara, Propinsi, Kabupaten, dan Kotamadya menurut provinsi dan jenis permukaan tahun 1995 harga konstan tahun 1995. 


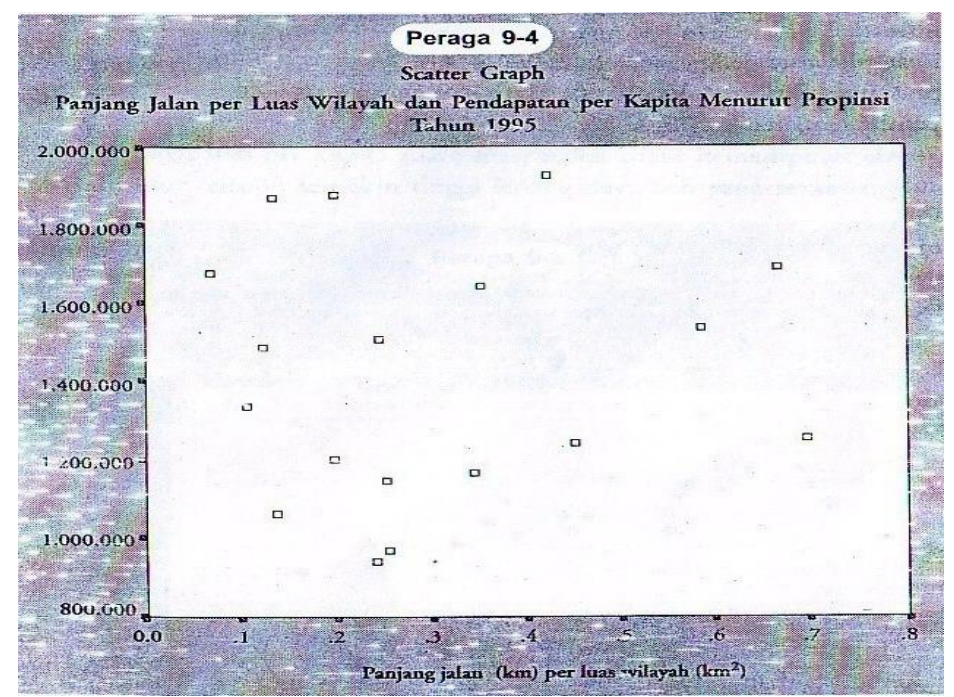

Gambar 6 : Keterkaitan antara Panjang Jalan per luas wilayah dengan GNP Per Kapita per Provinsi-provinsi.Tahun 1995

Sumber : Basri (2002:306)

Kesimpulan yang secara kasar dapat diambil berdasarkan gambar 6 adalah panjang jalan per luas wilayah memiliki korelasi positif. Pendapatan masyarakat didorong dari ketersediaan infrastruktur jalan yang baik adalah hal yang ditentukan oleh kesimpulan ini. Faktor ini disebabkan karena semakin lancarnya arus perdagangan akibat dari semakin tinggi mobilitas barang dan jasa. Selain kesimpulan diatas korelasi positif berarti juga memberi makna bahwa semakin tinggi pendapatan perkapita susatu daerah maka akan semakin tinggi pula kemampuan untuk menyediakan infrastruktur jalan karena kemampuan membayar pajak yang lebih tinggi dan daya beli masyarakat meningkat (Basri,2002:303-304)

Gambar 7 menggambarkan pemakaian energi, dalam kwh per kapita, sebagai fungsi Produk Domestik Bruto, dalam US\$ per kapita, sejumlah negara untuk tahun 1980. Gambar tersebut dibuat dalam skala logaritma, baik untuk PDB maupun pemakaian listrik. Sering dipakai Produk Nasional Bruto. Tampaknya ada semacam jalur lurus, yang secara diagonal bergerak melintasi gambar, dengan sebelah kiri bawah negara-negara industri yang lebih maju. 


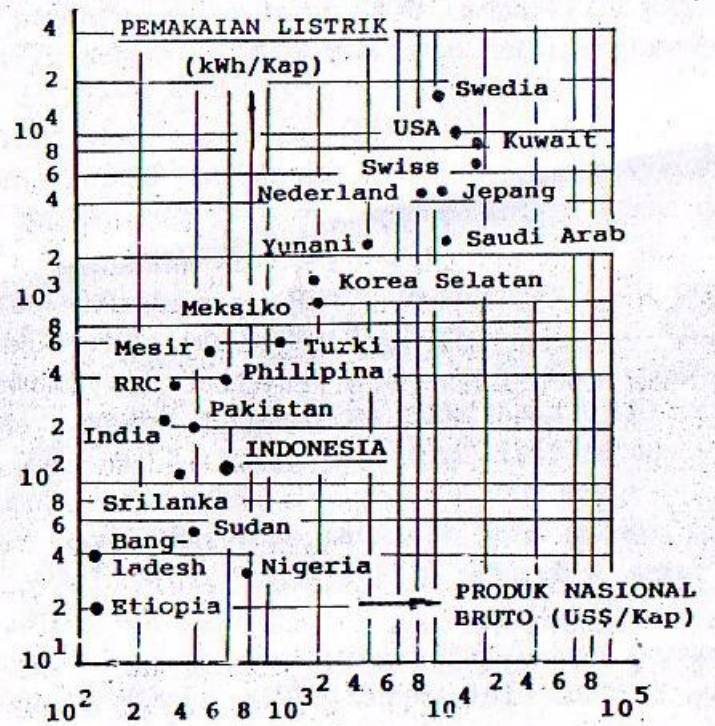

Gambar 7:Keterkaitan antara Infrastruktur Listrik dan GNP per kapita suatu negara.Tahun 1980

Sumber : Bank Dunia dalam Kadir (1995,560)

Dalam tabel 6 terlihat angka angka pertumbuhan Produk Nasional Bruto (PNB) dan pemakaian energi listrik dari tahun 1979 dari 14 negara maju, serta angka rata rata.

Untuk Indonesia. jumlah penduduk dalam tahun 1970 adalah 117,3 juta, dan dalam tahun 1979 sebanyak 143,7 juta, atau kenaikan rata rata setahun dengan 2,75 \%. Produk Domestik Bruto pada tahun 1970 berjumlah $5,182 \times 10^{12}$ rupiah dan dalam tahun 1979 sebsar 9,990 x $10^{12}$ rupiah, atau kenaikan rata rata setahun dengan 7,5\% dengan nilai uang konstan 1973.
Pemakaian energi komersial pada tahun 1970 berjumlah sebesar 9,851 juta TBE (tone batu bara ekuivalen) dan pada tahun 1979 sebanyak 33,1 juta TBE, atau peningkatan rata rata $14,4 \%$ setahun. Konsumsi energi listrik pada tahun 1970 sejumlah 2,918.10 kwh dan pada tahun 1979 naik dengan rata rata $10,523.10$ kwh, bermakna suatu kenaikan rata rata setahun dengan 15,4\%. Energi listrik ini berasal dari PLN maupun bukan PLN dan pembangkitan sendiri oleh industri. Angka angka tersebut diatas tercantum pada tabel 6. 
Tabel 6 : Jumlah Penduduk, Energi, Listrik, dan Elastisitas di Indonesia , 1970 dan 1979

\begin{tabular}{llllll}
\hline NO & \multicolumn{1}{c}{ Penjelasan } & \multicolumn{1}{c}{ Satuan } & $\begin{array}{c}\text { Tahun } \\
1970\end{array}$ & $\begin{array}{c}\text { Tahun } \\
1979\end{array}$ & $\begin{array}{c}\text { Naik } \% \\
\text { tahun }\end{array}$ \\
\hline 1 & $\begin{array}{l}\text { Jumlah } \\
\text { penduduk }\end{array}$ & Juta & 117,3 & 143,7 & 2,57 \\
\hline 2 & $\begin{array}{l}\text { Produk } \\
\text { Domestik Bruto }\end{array}$ & $10^{12}$ Rupiah & 5,182 & 9,990 & 7,5 \\
\hline 3 & PDB per Kapita & $\begin{array}{l}10^{12} \\
\text { Rupiah/Kapita }\end{array}$ & 44,2 & 67,7 & 4,8 \\
\hline 5 & $\begin{array}{l}\text { Konsumsi } \\
\text { listrik }\end{array}$ & $10^{9} \mathrm{kwh}$ & 2,918 & 10,523 & 15,4 \\
\hline 6 & $\begin{array}{l}\text { Listrik per } \\
\text { kapita }\end{array}$ & Kwh/K.T. & 24,9 & 73,2 & 12,7 \\
\hline 7 & Listrik: Energi & $\%$ & 9,87 & 10,59 & 0,8 \\
\hline 8 & $\begin{array}{l}\text { Listrik/K : } \\
\text { PDB/K }\end{array}$ & $\begin{array}{l}\text { Kwh/10 } \\
\text { Rupiah }\end{array}$ & 0,563 & 1,08 & 7,5 \\
\hline
\end{tabular}

Elastisitas Energi $=14,4: 7,5=1,92$

Elastisitas Listrik $=15,4: 7,5=2,05$

Sumber: Kadir (1995:563)

Dari tabel 6. dapat pula dilihat, bahwa pemakaian listrik per kapita dari tahun 1970 sampai 1979 naik dengan rata rata $12,7 \%$ setahun. Pula dapat dilihat bahwa komponen listrik dalam komposisi energi berjumlah sekitar 10\%. Tampak pula bahwa elastisitas energi berjumlah 1,92, sedangkan elastisitas listrik adalah sebesar 2,05. Adalah menarik juga untuk melihat komponen-komponen PDB Indonesia dan perkembangannya selama beberapa tahun, sebagaimana terlihat pada tabel 4.4

Menurut Kadir

$(1995: 564)$ pengaruh tenaga listrik terhadap produksi industri dapat dipelajari sebagai berikut:

a. Pengaruh dalam arti adanya tenaga listrik sehingga mendorong terbentuknya atau berkembangnya kegiatan industri. Hal ini memang telah menjadi perdebatan akademis. Manakah yang harus lebih dulu datang, listrik atau industri. Persoalan klasik ayam dan telur teranalogikan dengan hal ini.

b. Pengaruh harga tenaga listrik dalam struktur biaya produksi industri. 
Berapa besarkah komponen tenaga listrik sebagai unsur bagian biaya industri? Pengaruh ini akan coba diuraikan.

Penentuan bagian daripada biaya listrik dalam produksi secara keseluruhan suatu kegiatan industri dapat dilakukan dengan mempelajari tiga unsur yang terdiri atas: Biaya langsung energi listrik dalam pembuatan produk tersebut. Biaya energi listrik yang terkandung dalam produksi dan penyediaan bahan bakar dan bahan bahan lain yang diperlukan untuk pembuatan produk akhir yang dipelajari. Bagian biaya energi listrik yang termasuk didepresiasi aktiva tetap pabrik itu, seperti bangunan, mesin dan asset tetap lainya.

Suatu studi yang mempelajari biaya langsung harga energi listrik di suatu pabrik bir, pabrik rokok, pabrik sepatu dan pabrik ban memberikan hasilhasilnya sebagai mana terlihat pada table 7

Tabel 7 Pengaruh Energi Listrik Langsung Terhadap Produksi Beberapa Jenis Industri

\begin{tabular}{llllll}
\hline NO & Keterangan & \multicolumn{4}{c}{ PABRIK } \\
\cline { 3 - 6 } & & Bir & Rokok & Sepatu & Ban \\
\hline 1 & Pemakai listrik & $\begin{array}{l}3.057 .684 \\
\text { kwh }\end{array}$ & $364.522 \mathrm{kwh}$ & $843.170 \mathrm{kwh}$ & $\begin{array}{l}1.614 .120 \\
\mathrm{kwh}\end{array}$ \\
\hline 2 & Produksi & $\begin{array}{l}5.130 .100 \\
\text { liter }\end{array}$ & $\begin{array}{l}73.718 .650 \\
\text { bungkus }\end{array}$ & $\begin{array}{l}1.038 .258 \\
\text { pasang }\end{array}$ & $\begin{array}{l}393.093 \\
\text { buah }\end{array}$ \\
\hline 3 & Biaya & $6,4 \%$ & $0,41 \%$ & $2,45 \%$ & $4,7 \%$ \\
& Langsung & & & & 4,11 \\
\hline 4 & Listrik & 0,596 & 0,05 & 0,8 & 4,11 \\
\hline 5 & Listrik per & 0,569 & 0,05 & 0,8 & $\mathrm{kwh} / \mathrm{ban}$ \\
\hline
\end{tabular}

Sumber: Kadir dalam Kadir (1995:565)

Suatu studi lain yang mempelajari hal yang sama pada beberapa jenis industri lain seperti beras, gula, pemintalan tekstil dan semen memberikan angka angka sebagaimana tampak dalam tabel dibawah ini.

Data yang terdapat pada tabel 5 dan 6 merupakan angka-angka dari industri di Indonesia. Angka angka mengenai pemakaian energi per satuan produksi di luar negeri menurut Lincoln tercantum dalam tabel 9 berikut, yang menyangkut produk produk seperti alumunium, baja, listrik, alumina ex-bauxtie, gula dan rokok.

Kerancuan dalam pembahasan pengaruh infrastruktur telepon terhadap pertumbuhan ekonomi. Ada asumsi 
tentang perlunya telaah terhadap hubungan antara telokumunikasi dan pembangunan. Meskipun benar bahwa telekomunikasi disuatu negara tumbuh sebagai fungsi dari pertumbuhan ekonomi, namun juga sebaliknya, sehingga terjadi sumbangan timbal balik antara keduanya. Berbagai hasil studi ITU juga membuktikan bahwa penambahan fasilitas dan pelayanan telekomunikasi bukan hanya hasil dari pertumbuhan ekonomi, melainkan merupakan prasyarat bagi seluruh sektor pembangunan, dan pembangunan sarana telekomunikasi merupakan bagian esensial dari proses pembangunan nasional dan internasional.

Namun ada dua kesulitan yang kita hadapi dalam upaya menjawab pertanyaan mengenai signifikasi ekonomi telekomunikasi. Pertama sejauh ini adalah kurangnya bahan yang relevan, terutama hasil hasil studi empiris yang dillakukan di Indonesia sendiri yang berakibat kita sulit untuk menjawab. Berapa sumbangan panggilan telepon terhadap GNP?

Isu mengenai korelasi antara telekomunikasi dan pembangunan telah menjadi perhatian banyak peneliti. Salah satu adalah hasil penelitian oleh ITU dalam publikasinya "Telecomunicatiaon for Development" (1983) dan Information Telecomunication and Development" (1986).Dari penelian itu ditemukan beberapa hasil yang menarik. Intinya adalah, makin rendah tingkat GNP/P suatu negara, makin tinggi peranan telekomunikasi dalam meningkatkan GNP. Demikian pula sebaliknya, makin tinggi GNP/P suatu negara, makin kecil sumbangan telekomunikasi terhadap GNP. Rentang GNP/P yang dianalisis mulai yang ekstrim rendah (hanya US\$ 100) sampai ekstrim tinggi (US\$ 20.000).

Secara lebih rinci, temuan ITU adalah, pertama, kontribusi SST terhadap GNP makin tinggi dengan makin rendahnya tingkat GNP/P US\$ 100 kontribusi satu SST terhadap GNP adalah US\$ kontribusi satu SST terhadap GNP adalah US\$ 11.800, sedangkan pada tingkat GNP/P US\$ 20.000 sumbanganya hanya US\$ 390. Jadi, makin terbelakang suatu negara, makin tinggi sumbangannya setiap SST bagi pertumbuhan ekonomi. Adapun cutting point dimana telekomunikasi masih sangat besar sumbangannya adalah pada tingkat GNP/P US\$ 2000. Setelah itu, peranan telekomunikasi cenderung menurun. 
Kecenderungan ini mudah dipahami mengingat satu SST yang dibuka ke lokasi baru yang sebelumnya belum ada telepon, secara teoritis akan memberikan dampak pembangunan yang besar dengan tersedianya sarana telekomunikasi daripada telepon yang ke $n+1$ yang disediakan untuk daerah yang relatif padat dan tingkat industri serta ekonominya relatif maju.

Penelitian ITU menunjukan bahwa beberapa negara bahwa sektor telekomunikasi secara signifikan terhadap sektor industri dan manufaktur karena sektor sektor tersebut lebih memerlukan telekomunikasi daripada sektor pertanian yang ketergantungannya pada telekomunikasi lebih rendah.

Temuan kedua adalah sumbangan setiap percakapan telepon terhadap GNP merentang antara US\$ 3,93-11,80 untuk negara yang GNP/P nya US\$ 20.000 (pada tabel 3.2). Meskipun besarannya berbeda. Besar kecilnya sumbangan itu tergantung kepada tinggi-rendahnya GNP/P dan disektor mana serta dilokasi dengan karakteristik bagaimana telepon tersebut dibangun.

Temuan Ketiga, setelah memperhitungkan biaya pembangunan dan pemeliharaan, ratio keuntungan dan biaya (benefit and cost ratio) dari setiap SST berkisar antara 47:1 sampa 2:1. Makin rendah GNP/P, makin tinggi ratio keuntungan dan biaya (K/B) itu, dan makin tinggi GNP/P , makin rendah ratio itu. Artinya investasi US\$ 1000 untuk satu SST di negara yang GNP/P yang hanya US\$ 100, akan memberikan kentungan sebesar US\$ 47.000 sedangkan jika investasi dilakukan di negara yang GNP/P US\$ 20.000, keuntungan itu hanya dua kali lipat menjadi US\$ 2.000 (lihat tabel 4.7).

Tabel 13: Hasil Estimasi Faktor-faktor yang Mempengaruhi Impor Susu pada Jangka Pendek

\begin{tabular}{|l|l|l|}
\hline Variabel & Koefisien & Probabilitas \\
\hline Jalan & & \\
& $1.80 \mathrm{E}+11$ & 0.1594 \\
\hline Listrik & $-5.87 \mathrm{E}+08$ & 0.0615 \\
\hline Telepon & $1.28 \mathrm{E}+09$ & 0,2610 \\
\hline
\end{tabular}

Bahwa infrastruktur jalan tidak secara signifikan berpengaruh terhadap produk domestik bruto perkapita karena sifat infratsruktur yang mendukung 
perekonomian secara tidak langsung. Berdasarkan hasil penelitian yang dilakukan, kesimpulan yang dapat diambil untuk menjawab permasalahan yang diteliti, yaitu Ketersediaan infrastruktur publik (jalan, listrik dan telepon) yang dikaji dalam penelitian ini semuanya mempengaruhi Produk Domestik Bruto perkapita di Indonesia untuk jangka panjang. Ketersediaan infrastruktur publik (jalan, listrik dan telepon) yang dikaji dalam penelitian ini semuanya tidak mempengaruhi Produk Domestik Bruto perkapita di Indonesia untuk jangka pendek .

\section{DAFTAR PUSTAKA}

Albala-Bertrand, José Miguel and Mamatzakis, Emmanuel C., The Impact of Public Infrastructure on the Productivity of the Chilean Economy (February 2001). University of London Queen Mary Economics Working Paper No. 435. http://ssrn.com/abstract=261313 diakses pada 22 November 2009

Arsyad, Lincoln.2004.Ekonomi Pembangunan.(Edisi Keempat).BP STIE YKPN:Yogyakarta

Badan Pusat Statistik.1981.Buku Saku Statistik Indonesia 1980-1981 .Jakarta:Badan Pusat Statistik.
Badan Pusat Statistik.1983.Buku Saku Statistik Indonesia 1983.Jakarta:Badan Pusat Statistik.

Badan Pusat Statistik.1989.Buku Saku Statistik Indonesia 1989.Jakarta:Badan Pusat Statistik.

Badan Pusat Statistik.1994.Buku Saku Statistik

Indonesia1994.Jakarta:Badan Pusat Statistik.

Badan Pusat Statistik.1998.Buku Saku Statistik Indonesia 1998.Jakarta: Badan Pusat Statistik.

Badan Pusat Statistik.2002.Buku Saku Statistik Indonesia 2002.Jakarta:Badan Pusat Statistik

Badan Pusat Statistik.2002.Buku Saku Statistik Indonesia 2002.Jakarta:Badan Pusat Statistik

Badan Pusat Statistik.2007.Statistik Indonesia 2007.Jakarta:Badan Pusat Statistik

Baldwin, John R. and Dixon, Jay, Infrastructure Capital: What is it? Where is it? How Much of it is There? (March 12, 2008). Canadian Productivity Review Research Paper No. 16.http://ssrn.com/abstract $=150788$ 3 diakses pada 22 November 2009

Basri,Faisal.2002.Perekonomian Indonesia:Tantangan dan Harapan Bagi Kebangkitan Ekonomi Indonesia.Erlangga:Jakarta

Calderon, Cesar A. and Serven, Luis, The Effects of Infrastructure 
Development on Growth and Income Distribution (September 2004). World Bank Policy Research Working Paper No. 3400. http://ssrn.com/abstract $=625277$ diakses pada 22 November 2009

Canning, David, Infrastructure's Contribution to Aggregate Output (November 1999). World Bank Policy Research Working Paper No. 2246. http://ssrn.com/abstract $=629182$ diakses pada 22 November 2009

Case,Karl E,Fair,C Ray.2004.Prinsip prinsip Ekonomi Makro (Bambang Sarwiji).Indeks Kel Gramedia:Jakarta

Edquist,Herald and Henrekson,Magnus. Technological Breakthrough and Productivity Growth (May 2006).Research in Economic History Vol.24;Institute for research in Economic History;Research institute of Industrial Economics http://ssrn.com/abstract=996823 diakses pada 22 November 2009

Égert, Balázs, Kozluk, Tomasz J. and Sutherland, Douglas, Infrastructure and Growth: Empirical Evidence (July 14, 2009). CESifo Working Paper Series No. 2700; William Davidson Institute Working Paper No. 957; OECD Economics Department Working Paper No. 685.

http://ssrn.com/abstract $=1360784$ diakses pada 22 November 2009

Enders, W. 2004. Applied Economic Time Series. Wiley, Alabama
Garmendia Briceno, Cecilia, Estache, Antonio and Shafik, Nemat, Infrastructure Services in Developing Countries: Access, Quality, Costs, and Policy Reform (December 2004). World Bank Policy Research Paper No. 3468. http://ssrn.com/abstract $=643265$ diakses pada 22 November 2009

Kasim ,Surya Tarmizi.2006.Analisis Pengaruh Kinerja Listrik terhadap Pertumbuhan Ekonomi Indonesia.Univeristas Sumatera Utara:Medan http://ssrn.com/abstract $=1498978$ diakses pada 22 November 2009

Kadir,Abdul.1995:Energi:Sumber Daya,Inovasi,Tenaga Listrik dan Potensi Ekonomi (Edisi Kedua/Revisi).UI Press:Jakarta

Kuncoro,Mudrajad.2006.Ekonomi Pembangunan : Teori, Masalah dan Kebijakan.UPP STIM YKPN:Yogyakarta

Mangkoesoebroto,Guritno,Algifari.1998. Teori Ekonomi Makro(Edisi Ketiga).BP STIE YKPN:Yogyakarta

Mankiw,N Gregory.1997.Pengantar Ekonomi (Jilid II).(Imam Nurmawan).Erlangga : Jakarta

Mankiw, N Gregory.2003.Teori Makroekonomi(Edisi

Kelima).(Imam Nurmawan).Erlangga:Jakarta

Nachrowi,Djalal

Nachrowi,Usman,Hardius.2006:

Pendekatan Populer dan Praktis 
Ekonometrika untuk Analisis Ekonomi dan Keuangan.Lembaga Penerbit FE UI: Jakarta

Permana,Chandra Darma.2009.Analisis Peranan dan Dampak Investasi Infratsruktur terhadap Perekonomian Indonesia.Bogor:Fakultas Ekonomi dan Manajemen Institut Pertanian Bogor

(IPB). http://iirc.ipb.ac.id/jspui/bitstream/1 23456789/11590/2/H09cdp.pdf diakses pada 27 Juni 2010

Rahardja,Prahatma,Manurung,Mandala.2 005.Teori Ekonomi Makro (Suatu Pengantar)(Edisi Ketiga).Lembaga Penerbit FE UI:Jakarta

Seethepalli, Kalpana, Bramati, Maria Caterina and Veredas, David, How Relevant is Infrastructure to Growth in East Asia? (April 1, 2008). World Bank Policy Research Working Paper Series, Vol., pp. -, 2008. http://ssrn.com/abstract=1149100 diakses pada 22 November 2009

Sukirno,Sudono.2007.Ekonomi

Pembangunan:

Proses,Masalah,dan

Dasar

Kebijakan.Kencana Persada Media Group : Jakarta

Supriadi,Dedi.1996.Era Baru Bisnis Telekomunikasi.STT

Telkom:Bandung

Thomas, R.L. 1997. Modern Econometrics : an Introduction. Addison-Wesley, Essex.

Todaro,P Micahel, Smith C Stephen.2007.Pembangunan
Ekonomi di Negara Dunia Ketiga (Edisi kedembilan)Jilid1.(Haris Munanda,Puji

A.L).Jakarta:Erlangga

Um Paul Noumba, Straub, Stéphane and Vellutini, Charles, Infrastructure and Economic Growth in the Middle East and North Africa (October 1, 2009). World Bank Policy Research Working Paper Series, Vol. , pp. -, 2009. diakses pada 22 November 2009

Wahyuni, Krismanti Tri.2009.Analisis Pengaruh Infrastruktur Ekonomi dan Sosial Terhadap Produktivitas Ekonomi Indonesia.Bogor:Fakultas Ekonomi dan Manajemen.Institut Pertanian Bogor (IPB).http://iirc.ipb.ac.id/jspui/bitstr eam/123456789/13210/2/H09ktw.p df diakses pada 27 Juni 2010

Winarno,Wing Wahyu.2009.Analisis Ekonometrika dan Statistika dengan E Views (Edisi ke-2).UPP STIM YKPN:Yogyakarta.

World Bank(2010). Telephone lines. (per 100

people).http://data.worldbank.org/in dicator IT.MLT.MAIN.P2 diakses pada 26 Mei 2010

World Bank (2007).Kajian Pengeluaran Publik Indonesia Bab 5 Infrastruktur.

http://siteresources.worldbank.org/I NTINDONESIA/Resources/226271 1168333550999/PERFBAB5Infrastruktur.pdf diakses pada 22 November 2009 
World Bank(2010) .Electric power consumption( $k W h$ per capita). http://data.worldbank.org/indicator EG.USE.ELEC.KH.PC diakses pada 26 mei 2010

World Bank (2010).GDP (constant 2000 $U S \$)$.

http://data.worldbank.org/indicator NY.GDP.MKTP.KD diakses pada 26 Mei 2010
World Bank (2010).Mobile and fixed-line telephone subscribers(per 100 people).diakses pada 26 Mei 2010

World

Bank (2010)

.Population,total.http://data.worldba nk.org/indicator SP.POP.TOTL diakses pada 26 Mei 2010

www.bps.go.id/data/energi diakses pada 27 Juni 2010 
